Воропай Ю. В.

\title{
УДК 631.53.04:633.34(477.73)
}

ВПЛИВ НОРМ ВИСІВУ НАСІННЯ ТА СПОСОБІВ СІВБИ НА ФОРМУВАННЯ ПЛОЩІ ЛИСТЯ РОСЛИН НУТУ

Ю. В. ВОРОПАЙ, аспірант*

Харківський національний аграрний університет ім. В. В. Докучаєва

E-mail: voropay.julya@gmail.com

https://doi.org/10.31548/dopovidi2019.03.009

Анотація. У статті наведено результати досліджень 2016-2018 рр. із вивчення впливу норм висіву насіння та способів сівби на формування площі листя рослин нуту. Установлено, щз досліджувані технологічні чинники мали вплив на формування асиміляційної поверхні рослин нуту. У фазу цввітіння площа листкової поверхні рослин нуту за період вегетаиії була найбільшою $i$ коливалася від 10,32 до 16,03 тис. $\mathrm{M}^{2} / 2$ у у сорту Буджак $i$ від 10,68 до 17,15 тис.м²/га - в сорту Одисей. В усі досліджувані фази росту та розвитку рослин закономірність зміни площі листової поверхні залежно від норм висіву та способів сівби у досліді зберігалася. На варіантах рядкового способу сівби з шириною міжряддя 15 см та нормою висіву насіння 0,9 млн шт./га відмічено максимальні значення асиміляційної поверхні рослин нуту обох сортів.

Ключові слова: нут, норма висіву насіння, спосіб сівби, фаза розвитку, площуа листя

Постановка проблеми. Сучасні «виклики» сільському господарству глобальні кліматичні зміни, стрімкий ріст населення планети, загрозливі масштаби ерозії грунтів тощо, вимагають перегляду традиційних напрямків ведення сільського господарства. Пріоритетними завданнями залишаються збільшення валового виробництва рослинної продукції відповідної якості, перехід на екологічно чисті технології вирощування, розробка комплексу заходів, що передбачають захист грунтів від різних видів ерозії.

На сьогодні у світі «гостро» стоїть проблема дефіциту білка рослинного походження. У цьому контексті зростає значення бобових культур, як основного джерела рослинного білка. Поширення площ бобових культур попутно вирішуватиме ряд інших важливих завдань, зокрема, збагачення грунту азотом і відновлення його родючості, зростання ефективності сівозміни тощо [1]. Враховуючи сучасні кліматичні зміни, стан грунтів та ринкову кон'юнктуру, набуває актуальності поширення площ посіву бобових культур 3 високим адаптивним потенціалом [2].

\footnotetext{
*Науковий керівник - доктор сільськогосподарських наук, професор А. О. Рожков
} 
Агрономія

Воропай Ю. В.

Однією 3 таких культур є нут. Попит на цю культуру як в Україні так і в усьому світі має тенденції до зростання.

За останні 30 років світове виробництво нуту зросло майже вдвічі. Ареал вирощування нуту в Україні на сьогодні розширився далеко поза зону посушливого Степу i все більше фермерів починають вирощувати цю культуру [3, 4]. Подальше розширення посівних площ нуту неможливе без підвищення

конкурентноспроможності

виробництва цієї культури, насамперед врожайності насіння. Збільшити рівень реалізації генетичного потенціалу продуктивності нуту можна за рахунок оптимізації технології його вирощування. Тим більше, для цієї культури бракує детально розроблених $\mathrm{i}$ апробованих зональних технологій вирощування, тож іноді їі вирощують за «схемами» рекомендованими для інших бобових культур.

Аналіз останніх досліджень та публікацій. Значною мірою рівень розкриття біологічного потенціалу продуктивності

сільськогосподарських культур, нуту зокрема, залежить від площі живлення рослин i iii форми. Ці чинники визначають рівень конкурентної боротьби в агрофітоценозі i значною мірою впливають на показники

фотосинтетичної

продуктивності посівів.

Продуктивність будь-якого посіву тісно пов'язана 3 площею листової поверхні посівів, тож вживаючи заходи направлені на збільшення площі листя без надмірного загущення рослин, можна значно підвищити продуктивність рослин $[5,6]$.

Для формування максимальних показників фотосинтетичної діяльності посівів важливо передбачити оптимальний розподіл рослин по площі живлення, який забезпечується способом сівби i нормою висіву насіння. Підбір оптимальних комбінацій цих технологічних чинників, за умов достатнього зволоження і поживного режиму, може забезпечити формування потрібної площі листової поверхні та збільшення продуктивності посіву [7]. Таким чином, вивчення комплексного впливу норм висіву насіння та способів сівби на формування площі листя рослин нуту $\epsilon$ актуальним питанням, яке потребує детального вивчення.

Мета досліджень. Метою досліджень було встановлення комплексного впливу норм висіву насіння та способів сівби на формування площі листової поверхні посівів нуту різних сортів протягом вегетації.

Матеріали досліджень. методи

Експериментальні 
Воропай Ю. В.

дослідження проводили на базі ННВЦ «Дослідне поле» Харківського національного аграрного університету ім. В. В. Докучаєва в 2016-2018 pp. Грунт дослідних ділянок чорнозем звичайний середньогумусний глибокий важкосуглинковий. Вміст гумусу в орному шарі в середньому становить 4,6 \%, гідролізованого азоту - 116 мг на 1 кг грунту, рухомих форм фосфору і калію - 13,8 мг і 10,3 мг на 100 г грунту відповідно. Реакція грунтового розчину слабокисла (pH 5,7) [8]. Трифакторний польовий дослід було поставлено за повною факторіальною схемою відповідно до загальноприйнятої методики [9]. Ділянками першого порядку (чинник A) були два сорти нуту - Буджак i Одисей, внесені до Державного реєстру сортів у 2008 р. і у 2014 р. відповідно. Ділянками другого порядку (чинник $B$ ) були три варіанти способу сівби: рядковий iз міжряддям 15 і 30 см і широкорядний 3 міжряддям 45 см. Ділянками третього порядку (чинник $C$ ) виступали п'ять норм висіву насіння: 500; 600; 700; 800 і 900 тис. шт./га. Перед сівбою проводили інокуляцю насіння Ризобофітом. Площа посівної ділянки становила - 15 м $^{2}$, облікової $-10 \mathrm{M}^{2}$.

Гідротермічні умови під час вегетації нуту відрізнялись від показників кліматичної норми. Погодні умови вегетації посівів у 2016 р. характеризувалися підвищеними температурними показниками

(перевищення показників кліматичної норми у середньому на $\left.3,1{ }^{\circ} \mathrm{C}\right)$ i достатнім вологозабезпеченням $\quad(143 \%$ від норми). Погодні умови вегетації нуту в 2017 та 2018 рр. були посушливими (ГТК - 0,88 і 0,65 відповідно), також характеризувалися підвищеною температурою повітря - на 1,0 i $3,4^{\circ} \mathrm{C}$ вище за кліматичну норми, водночас вони були більш сприятливими для росту та розвитку рослин нуту.

Результати досліджень та їх обговорення. Установлено, що на розмір асиміляційної поверхні посівів нуту обох сортів істотно впливали досліджувані технологічні чинники, а саме, норми висіву насіння та варіанти способів сівби.

У фазу гілкування найбільша площа листя посівів обох досліджуваних сортів нуту була відмічена на варіантах 3 максимальною досліджуваною нормою висіву насіння 0,9 млн шт./га (рис. 1). Разом із цим, площа листя однієї рослини нуту обох сортів при цьому зменшувалась. 
Воропай Ю. В.
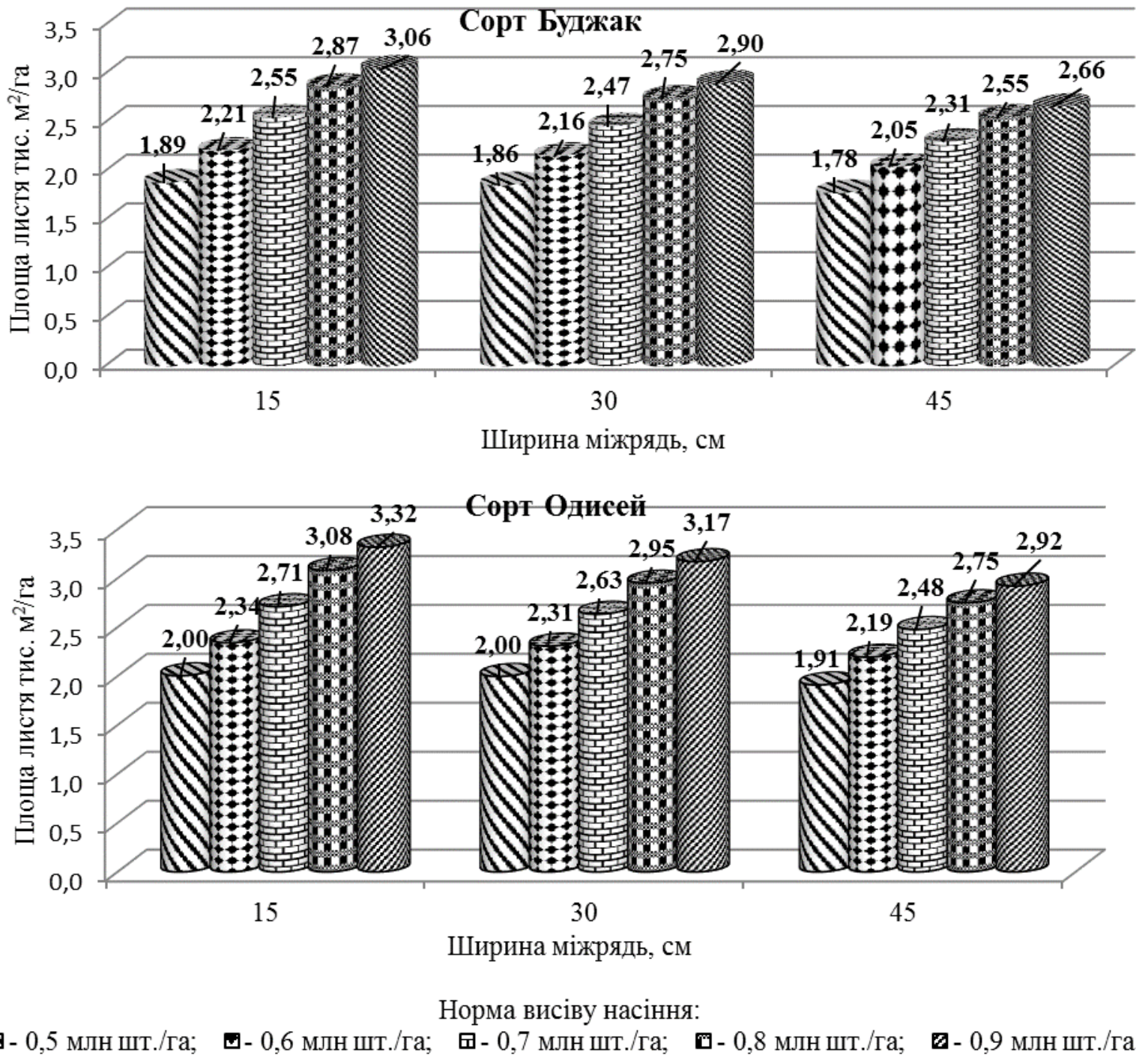

Рис. 1. Площа листкової поверхні посівів нуту у фазу гілкування, залежно від норм висіву насіння та способів сівби, тис. ${ }^{2} /$ га (середнє за 2016-2018 pp.)

У сорту Буджак за норм висіву насіння $\quad 0,5 ; \quad 0,6 ; 0,7 ; \quad 0,8 \quad$ i 0,9 млн шт./га площа листя $\mathrm{y}$ середньому за способами сівби становила 1,$84 ; 2,14 ; 2,44 ; 2,72$ і 2,87 тис. $\mathrm{м}^{2} /$ га.

Аналогічна закономірність була відмічена і на варіантах сорту Одисей - 1,97; 2,28;

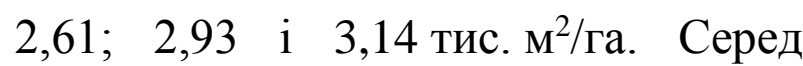
досліджуваних способів сівби найбільша площа асиміляційної поверхні в цю фазу була відмічена на варіантах рядкового способу сівби $з$

шириною міжряддя 15 см. Так, у середньому по нормах висіву насіння на варіантах 3 шириною міжрядь 15, 30 і 45 см, площа листя посівів нуту сорту Буджак становила 2,52; 2,43 i 2,27 тис. $\mathrm{m}^{2} /$ га, сорту Одисей - 2,69; 2,61 i 2,45 тис. м²/га відповідно. У фазі цвітіння площа листкової поверхні посівів нуту за впливу досліджуваних чинників коливалася від 10,32 до 16,03 тис. м²/га в сорту Буджак і від 10,68 до 17,15 тис. м²/га - в сорту Одисей (рис. 2). 

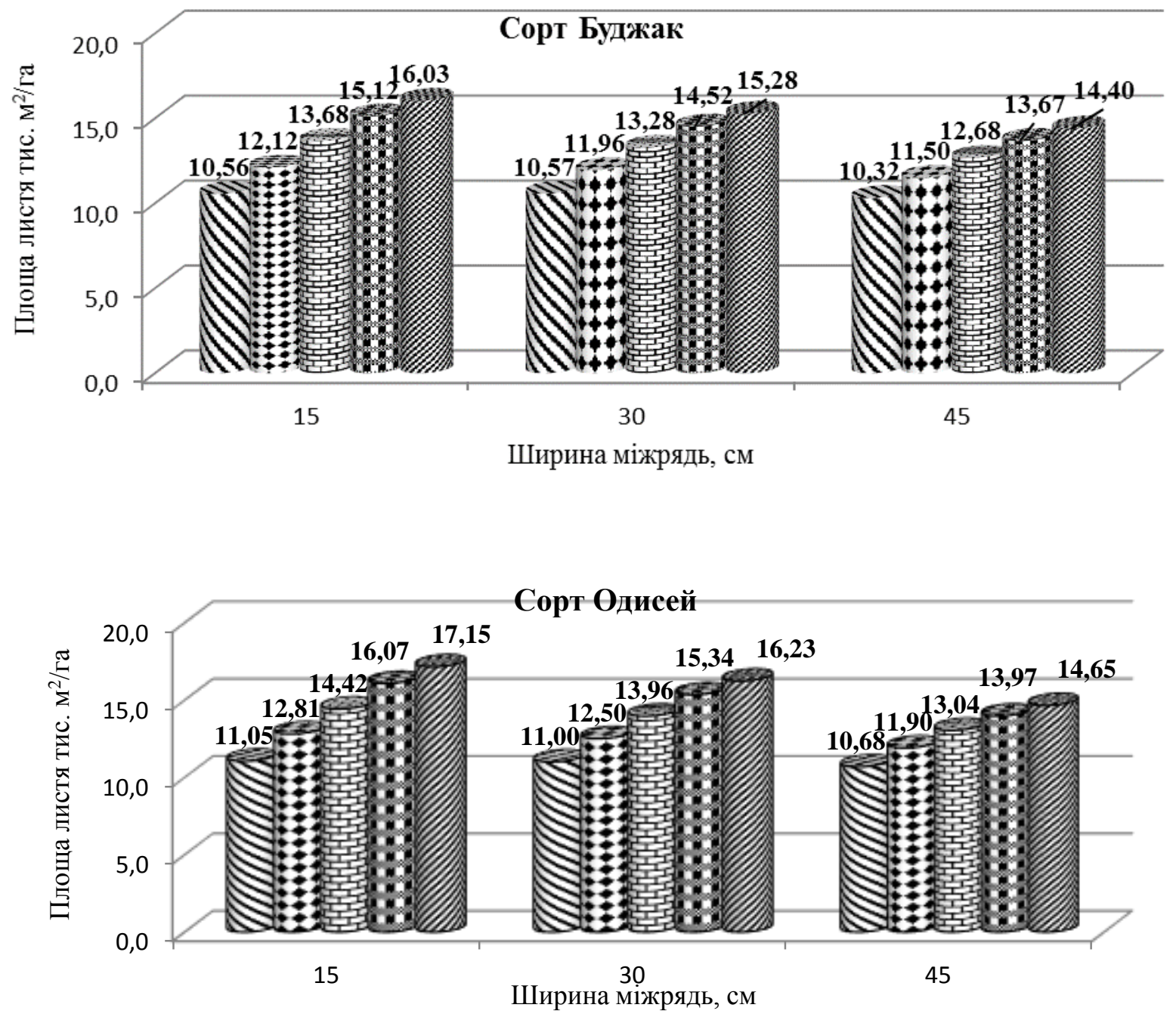

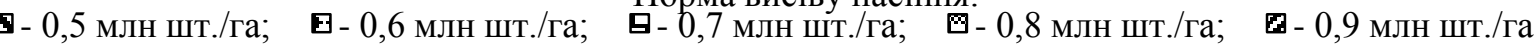

Рис. 2. Площа листкової поверхні посівів нуту а у фазу цвітіння, залежно від норм висіву насіння та способів сівби, тис. $\mathbf{m}^{2} /$ га (середне за 2016-2018pp.)

Як і у попередній фазі, у фазі цвітіння максимальна площа листя нуту обох сортів була на варіантах 3 нормою висіву насіння 0,9 млн шт./га. Зокрема, за норми висіву насіння 0,$5 ; 0,6 ; 0,7 ; 0,8$ i 0,9 млн шт./га площа листя нуту сорту Буджак становила 10,48; 11,86; 13,$34 ; 14,44$ i 15,24 тис. м $^{2} /$ га відповідно, у сорту Одисей - 10,91; 12,$41 ; 13,81 ; 15,13$ і 16,01 тис. м²/га.

Серед досліджуваних варіантів ширини міжрядь, максимальна площа листків нуту під час фази цвітіння була на варіантах із міжряддями - 15 см. Зокрема, у середньому по нормах висіву насіння, площа листя нуту сорту Буджак за ширини міжрядь 15, 30 i 45 см становила - 13,50; 13,12 i 12,51 тис. $\mathrm{m}^{2} /$ га, у сорту Одисей - 
Воропай Ю. В.

$14,30, \quad 13,81$ i 12,85 тис. $\mathrm{m}^{2} /$ га відповідно.

Аналіз досліджуваних чинників, як джерел мінливості площі листя посівів нуту показав домінуюче значення норми висіву насіння. Частка цього чинника у середньому за роки досліджень, становила - $88 \%$ (рис.3).

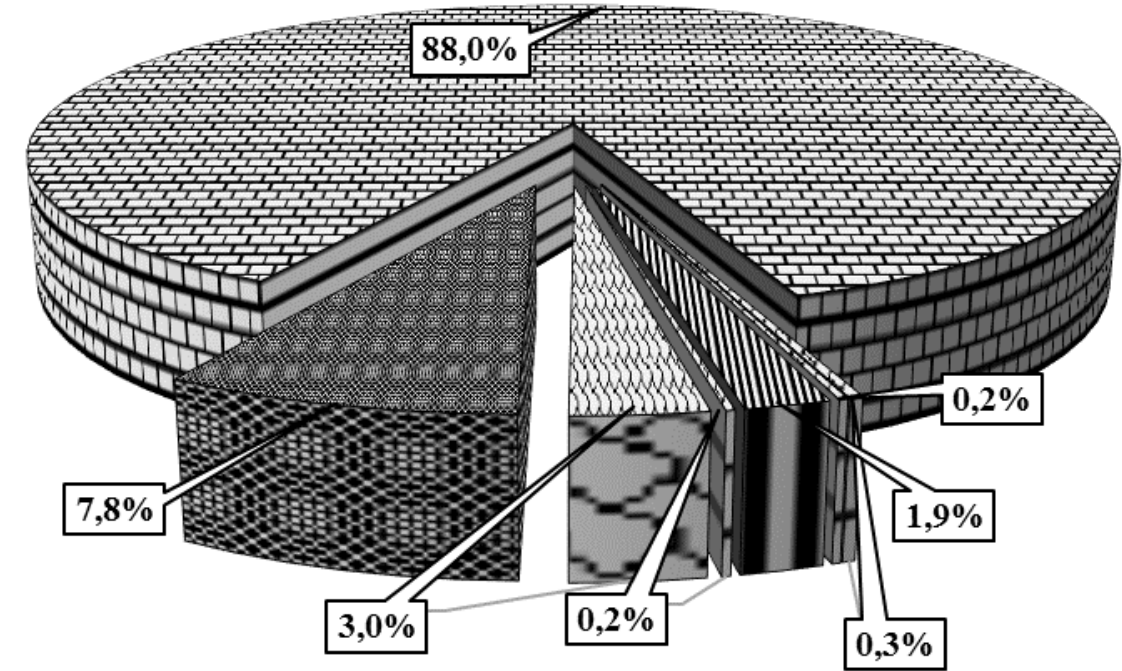

Ð $\operatorname{copт~(A);~}$ 囚 взаємодія $\mathrm{AC}$;
圈 спосіб сівби (В); ш взаємодія ВC; внорма висіву (C); 囚 взаємодія АВС

๑ взаємодія АВ;

Рис. 3. Вклад досліджуваних чинників у мінливість площі листя посівів нуту у фазу цвітіння, залежно від норм висіву насіння та способів сівби, \% (середнс за 2016-2018 рр.)

Серед головних ефектів досліджуваних чинників найменший вплив на загальну мінливість площі листя мав сорт $-3,0 \%$. Частка способу сівби становила 7,8 \%. Серед ефектів подвійної взаємодії найбільшою була взаємодія способу сівби та норми висіву насіння - 1,9 $\%$, що свідчить про високу ефективність комбінації ценотичних чинників. Варто зазначити, що аналогічна закономірність відмічена також у фазу гілкування та дозрівання.
У фазу дозрівання площа листя посівів нуту була меншою, ніж у фази гілкування та цвітіння. Варто відмітити, що закономірність зміни площі листкової поверхні залежно від норм висіву насіння та способів сівби у досліді збереглася. Максимальний показник площі листя посівів нуту сортів Буджак і Одисей - 4,00 і 4,10 тис. м²/га відповідно отримано на варіантах 3 найбільшою нормою висіву насіння і шириною міжряддя 15 см (рис. 4). 
Воропай Ю. В.
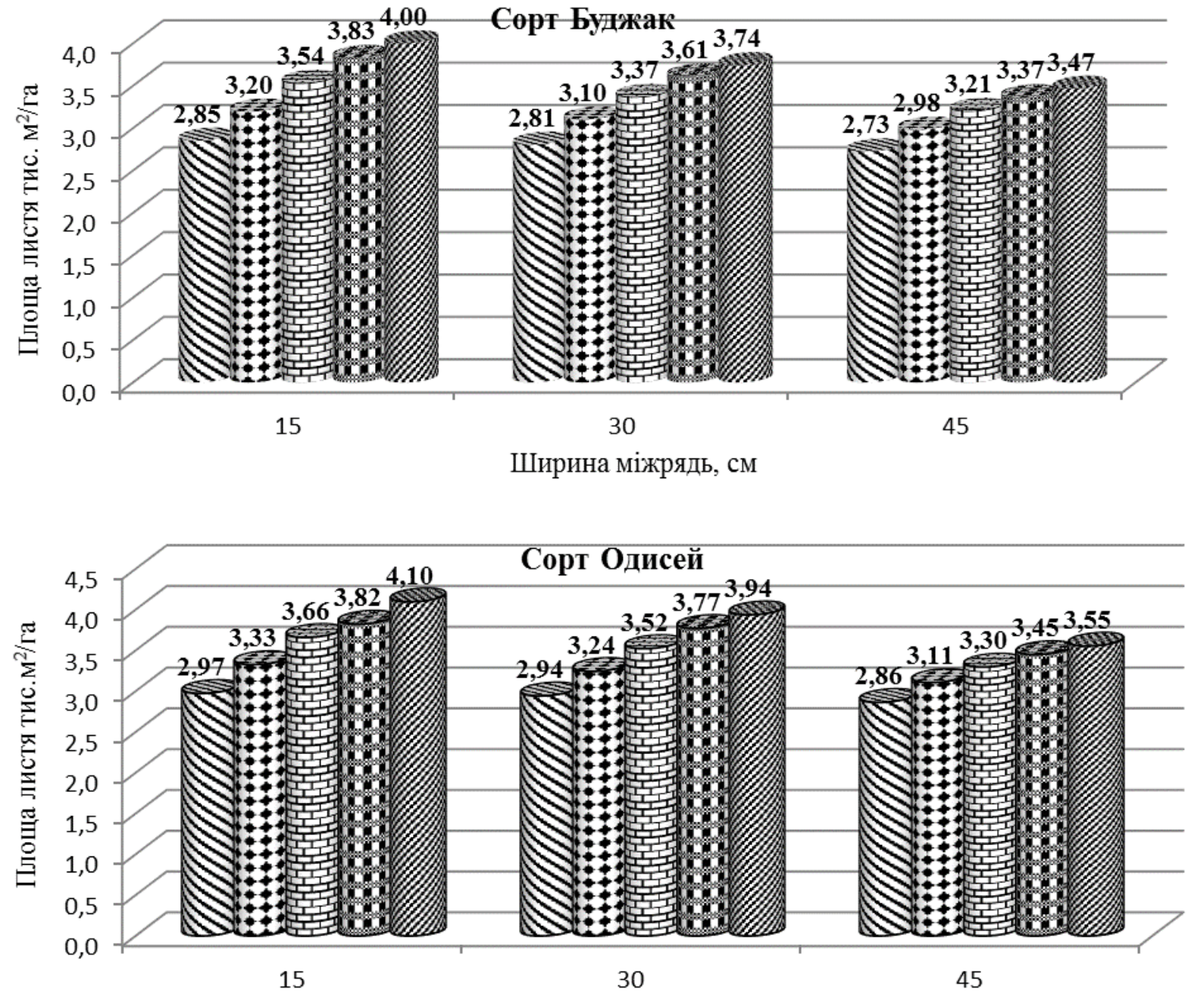

Ширина міжрядь, см

Норма висіву насіння:
凶- 0,5 млн шт./га;
๑ - 0,6 млн шт./га;
в - 0,7 млн шт./га;
由- 0,8 млн шт./га;
- 0,9 млн шт./га

Рис. 4. Площа листкової поверхні рослин нуту у фазу дозрівання, залежно від норм висіву насіння та способів сівби, тис. $\mathbf{m}^{2} / г а$ (середнс за 2016-2018 pp.)

Варто відмітити, що за умови розширення міжрядь від 15 см до 45 см відмічалось зменшення асиміляційної поверхні рослин нуту в усі фази проведення вимірювань. Також слід наголосити, що більшою мірою цей показник знижувався при розширенні міжрядь від 30 до $45 \mathrm{~cm}$, ніж від 15 до $30 \mathrm{~cm}$. Зокрема, у фазу цвітіння, площа листя рослин нуту сорту Одисей 3 розширенням

міжрядь від 15 до 30 см зменшувалась на 0,5 тис. $\mathrm{m}^{2} /$ га, а від 30 до 45 см - на 1,0 тис. $\mathrm{m}^{2} /$ га, аналогічна закономірність відмічена $\mathrm{i}$ у сорту Буджак.

Висновки.

Досліджувані технологічні чинники мали суттєвий вплив на мінливість площі листя посівів нуту. Установлено, що у фазу цвітіння площа асиміляційної поверхні рослин нуту сягає своїх 
Воропай Ю. В.

максимальних значень. Зокрема, у сорту Буджак, площа листя під час фаз гілкування, цвітіння і дозрівання в середньому становила - 2,40; 13,07 i 3,32 тис. $\mathbf{m}^{2} /$ га, в сорту Одисей 2,$58 ; 13,65$ i 3,44 тис. м $^{2} /$ га. В обох досліджуваних сортів площа листової поверхні посівів має чітко виражену тенденцію до підвищення зі збільшенням норми висіву насіння. Разом із тим, за поступового підвищення норми висіву насіння на крок градації (0,1 млн шт./га) приріст

\section{Список використаних джерел}

1. Куц В. Практики о выращивании нута. Зерно 2011. № 2 (58). C. 60.

2. Січкар В. I. Бобова для сівозмін Півдня. The Ukrainer Farmer 2017. № 10 (94). C. 68-72.

3. Січкар В. I. Відлуння нутового буму. The Ukrainer Farmer 2019. Березень № 3 (111), С. 118.

4. Січкар В. I. Технологія для нуту. The Ukrainer Farmer 2019. Січень № 1 (109), С. 26.

5. Бушулян О. В., Січкар В. I. Нут: генетика, селекція, насінництво, технологія вирощування: монографія. Одеса, 2009. 248c.

6. Каленська С. М., Щербакова О. М., Гончар Л. М. Асиміляційна діяльність посівів нуту залежно від сортових особливостей та передпосівної обробки насіння. Вісник СНАУ 2014. № 9 (28). С. 110111.

7. Зінченко О. І., Салатенко В. Н., Білоножко М. А. Рослинництво. К.: Аграрна освіта, 2001. 591 с.

8. Дегтярьов B. B. Гумус чорноземів лівобережного Лісостепу показника площі листя поступово зменшується. Тож збільшення площі листя 3 підвищенням норми висіву насіння від 0,8 до 0,9 млн шт./га було найменшим. Способи сівби також впливали на мінливість показника площі листя нуту, проте їх вплив був значно меншим ніж норм висіву. Розширення міжрядь від 15 до $30 \mathrm{~cm}$ призводило до значно меншого зниження площі листової поверхні в досліджувані фази розвитку рослин, ніж від 30 до 45 см.

і Степу України: монографія. Харків: Майдан, 2011. 360 с.

9. Рожков А. О., Пузік В. К., Каленська С. М. Дослідна справа в агрономії: навч. посібник: у 2 кн. Кн.1. Теоретичні аспекти дослідної справи. За ред. А. О. Рожкова. Х.: Майдан, 2016. 316 с.

\section{References}

1. Kuts V. (2011). Praktyky o vyrashchyvanyy nuta. [Practicians about chickpea cultivation]. Zerno. № 2 (58). S. 60. [in Ukrainian].

2. Sichkar V. I. (2017). Bobova dlia sivozmin Pivdnia. [Legumes for the rotation of the South]. The Ukrainer Farmer. № 10 (94). S. 68-72. [in Ukrainian].

3. Sichkar V. I. (2019). Vidlunnia nutovoho bumu. [Echoes of the chickpea boom]. The Ukrainer Farmer. Berezen № 3 (111). S. 118. [in Ukrainian].

4. Sichkar V. I. (2019). Tekhnolohiia dlia nutu. [Technology for Chickpea]. The Ukrainer Farmer. Sichen № 1 (109). S. 26. [in Ukrainian].

5. Bushulian O. V., Sichkar V. I. Nut: henetyka, selektsiia, nasinnytstvo, 
Воропай Ю. В.

tekhnolohiia monohrafiia.

vyroshchuvannia: breeding, seed production, technology of cultivation: monograph]. Odesa, 2009. 248 s. [in Ukrainian].

6. Kalenska S. M., Shcherbakova

O. M., Honchar L. M. (2014). Asymiliatsiina diialnist posivi nutu zalezhno vid sortovykh osoblyvostei ta peredposivnoi obrobky nasinnia. [Assimilation activity of chickpea crops, depending on varietal characteristics and pre-sowing treatment of seeds]. Visnyk SNAU. № 9 (28). S. 110-111. [in Ukrainian].

7. Zinchenko O. I., Salatenko V. N., Bilonozhko M. A. (2001). Roslynnytstvo. [Plant Growing]. K.: Ahrarna osvita. 591 s. [in Ukrainian].
8. Dehtiarov V. V. (2011). Humus chornozemiv livoberezhnoho Lisostepu i Stepu Ukrainy: monohrafiia. [Humus of black soils in Left-Bank ForestSteppe and Steppe of Ukraine: monograph]. Kharkiv: Maidan. 360 s. [in Ukrainian].

9. Rozhkov A. O., Puzik V. K., Kalenska S. M. (2016). Doslidna sprava $\mathrm{v}$ ahronomii: navch. posibnyk: u $2 \mathrm{kn}$. Kn.1. Teoretychni aspekty doslidnoi spravy. Za red. A. O. Rozhkova. Kh.: [Experiment in Agronomy: Teaching. manual: 2 books. - Book1. Theoretical aspects of the experiment. Ed. by A. O. Rozhkov]. Maidan. 316 s. [in Ukrainian].

\section{ВЛИЯНИЕ НОРМ ВЫСЕВА СЕМЯН И СПОСОБОВ СЕВА НА ФОРМИРОВАНИЕ ПЛОЩАДИ ЛИСТЬЕВ РАСТЕНИЙ НУТА}

\section{Ю. В. Воропай}

Аннотация. В статье приведены результаты исследований 2016-2018 г2. из изучения влияния норм высева семян и способов сева на формирование площади листьев растений нута. Установлено, что исследуемые технологические факторы имели влияние на формирование ассимилячионной поверхности растений нута.

В фазу цветения площадь листовой поверхности растений нута за период

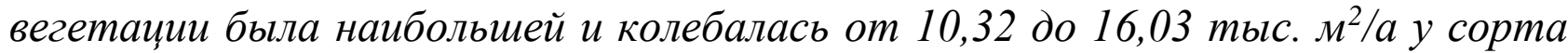

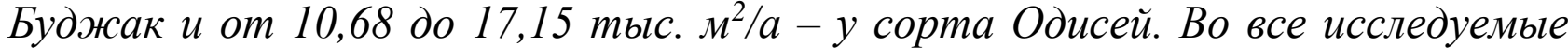
фазы роста и развития растений закономерность изменения площади листовой поверхности в зависимости от норм высева семян и способов сева в опыте сохранялась. При условии расширения междурядий от 15 см до 45 см отмечалось уменьшение ассимиляционной поверхности растений нута во все фазы проведения измерений. В большей степени этот показатель снижался при расширении междурядий от 30 до $45 \mathrm{~cm}$, чем от 15 до 30 см. На вариантах рядового способа сева с шириной междурядья 15 см и нормой высева семян 0,9 млн шт./га отмечены максимальные значения ассимиляиионной поверхности растений нута обоих сортов.

Ключевые слова: нут, норма высева семян, способ сева, фаза развития, площчадь листьев 


\section{THE EFFECT OF SEEDING RATES AND SOWING METHODS ON THE FORMATION OF CHICKPEA PLANT LEAVES AREA Y. V. Voropai}

Abstract. The article presents the results of studies for 2016-2018 years about the effect of seeding rates and seeding methods on the chickpea plant leaf area formation. It was established that the studied technological factors influenced the formation of the chickpea plants assimilation surface.

During the flowering phase, the leaf surface area of chickpea plants was the largest and ranged from 10.32 to 16.03 th. $\mathrm{m}^{2} / \mathrm{ha}$ in the Budjak variety and from 10.68 to 17.15 th. $\mathrm{m}^{2} / \mathrm{ha}$ in the Odyssey variety. In all the studied phases of plant growth and development, the pattern of leaf area variability, depending on the seeding rates and sowing methods, was maintained in the experiment. Assuming the row spacing extension from $15 \mathrm{~cm}$ to $45 \mathrm{~cm}$, a decrease the chickpea plants assimilation surface in all phases of the measurements was noted. This index decreased to a greater extent with the expansion of the row spacing from 30 to $45 \mathrm{~cm}$, than from 15 to $30 \mathrm{~cm}$. In the variants of the row sowing method with a $15 \mathrm{~cm}$ row spacing and a seeding rate of 0.9 million psc / ha the maximum values of the chickpea plants assimilation surface in both varieties were noted.

Keywords: chickpea, seeding rate, sowing method, development phase, leaf area 